\title{
Surface Modification of Mg-3Zn-0.8Ca Alloy Using Dual Micro-arc Oxidation (MAO) and Fluoridated Hydroxyapatite (FHA) Coatings
}

\author{
S.M. Abd El Hallem, I.M. Ghayad", N. Nassif", M.A. Shoeib*, \\ M.A. Maamoun* and H. Soliman* \\ Chemistry Department, Faculty of Science, Zagazig University, \\ Zagazig, and *Corrosion Control \& Surface Protection Lab., \\ Central Metallurgical Research and Development Institute, \\ CMRDI, P.O. Box: 87, Helwan, Cairo, Egypt.
}

\begin{abstract}
$\mathrm{S}$ OME unsolved problems currently limit the use of $\mathrm{Mg}$ alloys for orthopedic application. Firstly, the coatings usually have poor adhesion if they are applied without an appropriate pre-treatment. Secondly, it is difficult to prepare a uniform, pore-free layer. The present article aims to overcome these obstacles and improve the corrosion resistance of the $\mathrm{Mg}$ alloy via combination between surface treatment and electrodeposition. The alloy surface was pretreated using micro-arc oxidation (MAO) to form an oxide layer upon which a top layer of fluoridated-hydroxyapatite (FHA) was electrodeposited. The corrosion behavior of both layers was evaluated in simulated body fluid (SBF) using potentiodynamic polarization and electrochemical impedance techniques. Surface characterization of the FHA, MAO, and MAO/FHA coatings was performed. Results show that MAO treatment decreases the corrosion current ( $\mathrm{i}_{\text {corr }}$ ) of the $\mathrm{Mg}$ alloy from $7.5 \times 10^{-5} \mathrm{~A} \mathrm{~cm}^{-2}$ to $1.19 \times 10^{-6} \mathrm{~A} \mathrm{~cm}^{-2}$ and also increases the polarization resistance $\left(R_{p}\right)$ about 6 times compared to the untreated alloy. FHA coat further enhances corrosion resistance of the alloy as shown by the increase of $R_{p}$ by 14 times compared to the uncoated alloy. Pores blocking at MAO layer via FHA as top coat plays a key role in obvious corrosion resistance enhancement.
\end{abstract}

Keywords: Magnesium alloys, Implants, Micro-arc oxidation (MAO), Corrosion and Fluoridated hydroxyapatite (FHA).

Recently, significant interest has been generated in the application of bioactive implant materials and bioactive coatings for implants. Various studies ${ }^{(1-6)}$ have shown that magnesium alloys have a promising future as biodegradable implant materials. It is exciting to note that the biodegradation of magnesium alloys will keep the patient from second surgery. However, the main obstacle to the clinical use of magnesium alloys is their high corrosion rate. The high corrosion rate induced a mismatch with the bone healing rate and a gap formed between the implant and the surrounding tissue ${ }^{(7)}$. A controllable corrosion rate combined with biocompatibility plays a key role in the application of magnesium alloys in medical implants.

\#E-mail: ighayad@yahoo.com 
Micro-arc oxidation (MAO) technique is an effective way to slow down the corrosion rate of magnesium alloys ${ }^{(8-12)}$. MAO treatment fabricates porous ceramic coatings which posses both high adhesion to substrate and high corrosion resistance. However, MAO coatings have also some disadvantages; MAO exhibits poor biological activity because the main composition of MAO is magnesium oxide $\mathrm{MgO}^{(13)}$. To make things even worse, $\mathrm{MgO}$ is likely to change into soluble $\mathrm{Mg}^{2+}$ by the aid of $\mathrm{Cl}^{-(14)}$ for the unsealed MAO specimen and cannot protect magnesium substrate constantly.

As flouridated hydroxyapatite (FHA) has excellent biocompatibility and bioactivity, it is widely coated on metallic substrates for bio-application ${ }^{(15,16)}$. The electrochemical deposition (ED) technique could fabricate a uniform coating on a porous substrate or one with a complex shape and adjust the morphology and compositions of $\mathrm{Ca}-\mathrm{P}$ coating easily ${ }^{(10)}$. However, single FHA coating obtained through electrochemical deposition has a low bonding strength (about 4-6 MPa), which may lead to peeling off after implantation ${ }^{(11,12)}$.

As micro-arc oxidation can fabricate porous ceramic coating with high adhesion to substrate, it is expected that this porous coating can be used as the intermediate layer for depositing HA. It can generate pinning force when HA is deposited in the pores ${ }^{(9)}$ and enhance the corrosion resistance of the porous layer. Thus, fabricating a FHA coating on the MAO layer may be a promising way to improve the biocompatibility and corrosion resistance of magnesium alloys.

In this article, MAO and ED techniques were used to fabricate $\mathrm{MgO} /$ Fluoridated-Hydroxyapatite dual high quality coatings on $\mathrm{Mg}-3 \mathrm{Zn}-0.8 \mathrm{Ca}$ alloy. This alloy was selected because of its contents of $\mathrm{Zn}$ and $\mathrm{Ca}$. These elements are suitable candidates because they enhance corrosion resistance and mechanical properties of the alloy while they are very safe for human body. The function of the deposited coatings is to increase bonding strength between the coat and alloy surface and to improve the biocompatibility property of the alloy by depositing FHA on the surface and in the pores of MAO layer.

\section{Experimental Procedure}

\section{Preparation of dual MAO and ED coatings}

Mg-3Zn-0.8Ca alloy prepared in Central Metallurgical Research and Development Institute (CMRDI), Metal Casting Lab. was used as substrate in this work. Specimens having dimensions of $25 \times 10 \times 4 \mathrm{~mm}$ were prepared, polished with SiC papers progressively up to 1000 grits and finally subjected to ultrasonic cleaning in ethanol for $15 \mathrm{~min}$. During the process of MAO, the sample was used as the anode. The optimum bath composition and operating condition are given in Table 1. The elecreodeposition of FHA on MAO layer was carried out in two-electrode cell equipped with graphite plate serving as the counter electrode while the $\mathrm{Mg}$ alloy substrate was used as the cathode. The optimum bath composition and operating conditions are given in Table $2 . \mathrm{H}_{2} \mathrm{O}_{2}$ was introduced to only produce $\mathrm{OH}^{-}$ions on the cathode during the electrodeposition

Egypt. J. Chem. 57, No. 2 (2014) 
process instead of the usual case which produces $\mathrm{H}_{2}$ gas. Therefore, $\mathrm{H}_{2} \mathrm{O}_{2}$ could reduce the effect of $\mathrm{H}_{2}$ evolution on the nucleation and growth of FHA. After deposition, the specimens were rinsed in distilled water and then dried.

\section{Surface characterization}

The phase analyses of the coatings were carried out using Bruker AXS-D8 Xray diffractometer with $\mathrm{Cu}-\mathrm{K} \alpha$ radiation source at $40 \mathrm{kV}$ and $40 \mathrm{~mA}$, ADVANCE, Germany. The morphology and composition of coatings were observed under scanning electron microscope (SEM, JEOL, JSM 5410, Japan) equipped with energy dispersive spectroscopy (EDS) unit.

\section{Electrochemical measurements}

The optimum bath composition and operating parameters for both microarc oxidation treatment and electrodeposition of fluoridated hydroxiapatite on the $\mathrm{Mg}-\mathrm{Ca}-\mathrm{Zn}$ alloy are shown in Tables $1 \& 2$.

TABLE 1. Optimum bath composition and operating conditions of the MAO treatment on the Mg-Ca-Zn alloy.

\begin{tabular}{|c|c|c|c|}
\hline Chemicals & Weight & \multicolumn{2}{|c|}{ Operating conditions } \\
\hline $\mathrm{NaOH}$ & $10 \mathrm{~g} / \mathrm{L}$ & Current & $100 \mathrm{~V}$ \\
$\mathrm{Na}_{2} \mathrm{SiO}_{3}$ & $10 \mathrm{~g} / \mathrm{L}$ & Time & $30 \mathrm{~min}$ \\
\hline
\end{tabular}

TABLE 2. Optimum bath composition and operating conditions of the ED of fluoridated hydroxylapatite on MAO coat.

\begin{tabular}{|c|c|c|}
\hline Chemicals & Weight & Role \\
\hline $\begin{array}{c}\mathrm{CaNO}_{3} \\
\mathrm{NH}_{4} \mathrm{H}_{2} \mathrm{PO}_{4} \\
\mathrm{NaNO}_{3} \\
\mathrm{H}_{2} \mathrm{O}_{2} \\
\mathrm{NaF} \\
\mathrm{Na}_{3} \mathrm{PO}_{4}\end{array}$ & $\begin{array}{c}0.042 \mathrm{~mol} / 1 \\
0.025 \mathrm{~mol} / 1 \\
0.15 \mathrm{~mol} / \mathrm{l} \\
20 \mathrm{ml} / \\
0.2 \mathrm{~g} / \mathrm{l} \\
2 \mathrm{~g} / \mathrm{l}\end{array}$ & $\begin{array}{c}\text { Source of } \mathrm{Ca}^{2+} \text { ions } \\
\text { Source of } \mathrm{PO}^{3+} \text { ions } \\
\text { Increase conductivity } \\
\text { Erase gas evolution } \\
\text { Source of } \mathrm{F}^{-} \text {ions } \\
\text { Buffer }\end{array}$ \\
\hline \multicolumn{3}{|c|}{ Operating conditions } \\
\hline $\begin{array}{c}\text { Current density } \\
\text { pH } \\
\text { Time } \\
\text { Agitation } \\
\text { Temperature }\end{array}$ & & $\begin{array}{c}20 \mathrm{~mA} / \mathrm{cm}^{2} \\
3.8 \\
30 \mathrm{~min} \\
300 \mathrm{rpm} \\
\text { Room temperature }\left(25^{\circ} \mathrm{C}\right)\end{array}$ \\
\hline
\end{tabular}

Electrochemical measurements were performed using a computerized potentiostat (Autolab PG STAT 30) in simulated body fluid (SBF) whose composition was: $8.8 \mathrm{~g} / \mathrm{l} \mathrm{NaCl}, 0.4 \mathrm{~g} / \mathrm{l} \mathrm{KCl}, 0.14 \mathrm{~g} / \mathrm{l} \mathrm{CaCl} 2,0.35 \mathrm{~g} / 1 \mathrm{NaHCO}_{3}, 1.0$ 
g/l $\mathrm{C}_{6} \mathrm{H}_{6} \mathrm{O}_{6}$ (glucose), $0.2 \mathrm{~g} / \mathrm{l} \quad \mathrm{MgSO}_{4} 7 \mathrm{H}_{2} \mathrm{O}, 0.1 \mathrm{~g} / \mathrm{KH}_{2} \mathrm{PO}_{4} \cdot \mathrm{H}_{2} \mathrm{O}, 0.06 \mathrm{~g} / \mathrm{l}$ $\mathrm{Na}_{2} \mathrm{HPO}_{4} \cdot 7 \mathrm{H}_{2} \mathrm{O}, \mathrm{pH} 7.4$, at a temperature of $37^{\circ} \mathrm{C}^{(17)}$. A conventional three-electrode cell was used in conducting electrochemical tests. Alloy sample, a platinum counter electrode and a saturated calomel electrode were used as the working, counter and reference electrodes; respectively. The area of the working electrode exposed to the solution was $0.196 \mathrm{~cm}^{2}$. Potentiodynamic polarization experiments were measured at a scan rate of $0.5 \mathrm{mVs}^{-1}$ starting from the less to the more noble potentials. The electrodes were preirnmersed for $15 \mathrm{~min}$ in the testing solution before testing. Electrochemical impedance spectroscopy (EIS) measurements were performed at frequencies ranged from $60 \mathrm{kHz}$ to $10 \mathrm{mHz}$, and the perturbation amplitude was $5 \mathrm{mV}$.

\section{Results and Discussion}

\section{Surface characterization}

Figure 1(a) shows the surface morphology and structure of the FHA coated sample. The coating surface exhibited either regular flake-like structure diverging from centre toward periphery or irregular flake-like structure with different dimensions. Figure 1(b) shows the surface morphology of the MAO coated sample. It can be seen that the surface is covered completely with $\mathrm{MgO}$ layer. This layer contains some pores that vary in size from small to relatively large. These pores formed by the molten oxide and gas bubbles which are emitted out of the Micro-arc discharge channels. Figure 1(c) shows the surface morphology of the MAO/FHA coated sample. It can be seen that the surface is completely covered by FHA layer which can be attributed to the high porosity of the MAO layer offering considerable sites where FHA particles are easily incorporated.

The EDS analysis of coated samples is shown in Fig. 2. EDS spectra indicate that the MAO coating was mainly composed of $\mathrm{Mg}, \mathrm{O}$ and a small amount of other elements. The presence of $\mathrm{Ca}, \mathrm{Na}$ and $\mathrm{K}$ in the MAO coating suggests that the cation species in the aqueous solution are incorporated into the discharge channels during the MAO process. After electrodeposition of FHA, the $\mathrm{Ca} / \mathrm{P}$ molar ratio of the FHA coating is about 1.1 and so the coat mostly composed of Ca-deficient HA.

Egypt. J. Chem. 57, No. 2 (2014) 


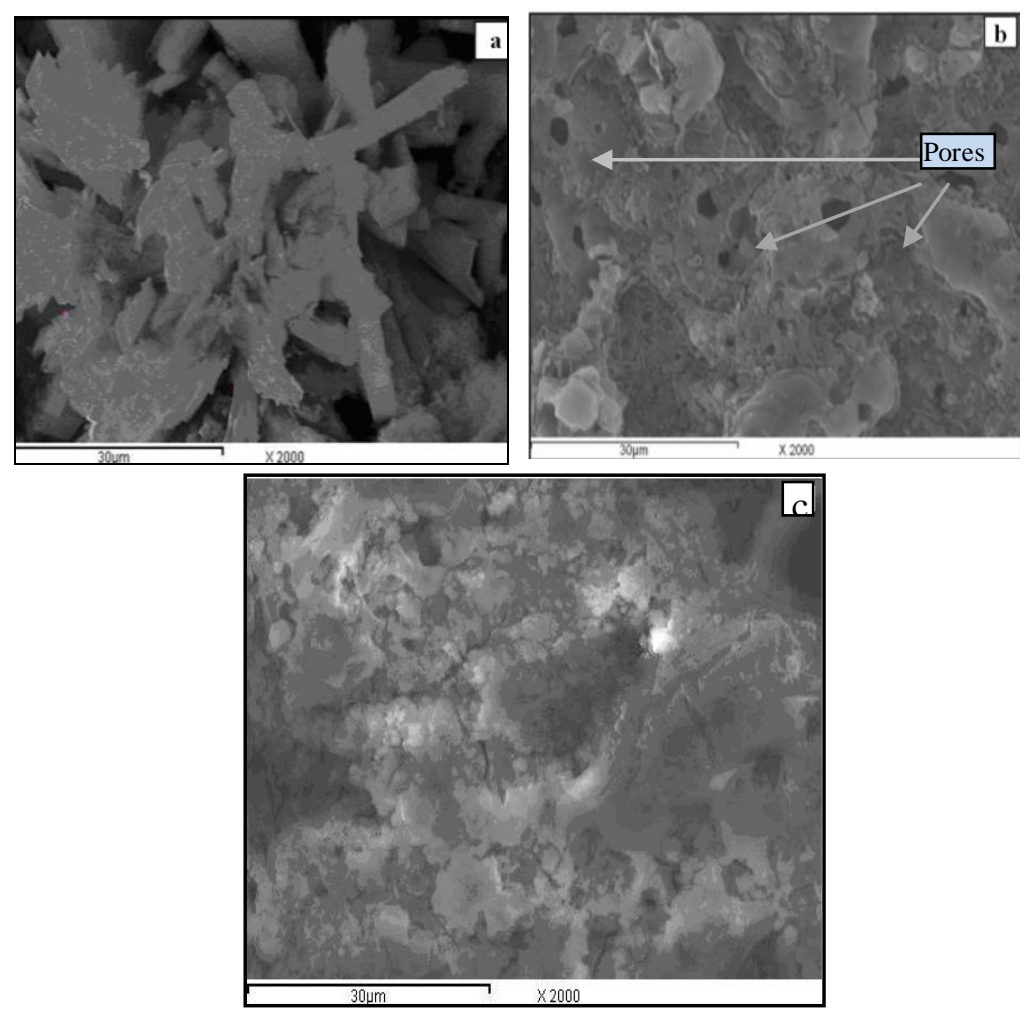

Fig. 1. SEM images of the Mg-Zn-Ca alloy surface treated under the following conditions: (a) FHA coat; (b) MAO coat; (c) MAO/FHA coat .

This Ca-deficient coating can meet the requirements for biodegradable implant and may induce the precipitation of a new bone-like apatite rapidly after implantation $^{(18,19)}$.

$X$-Ray diffraction (XRD) analysis

Figure 3 presents the XRD patterns of FHA and MAO/FHA coated samples. The pattern of FHA coating shows peaks of FHA and Mg. This indicates that the FHA layer does not well cover or adhere to the Mg alloys surface. 

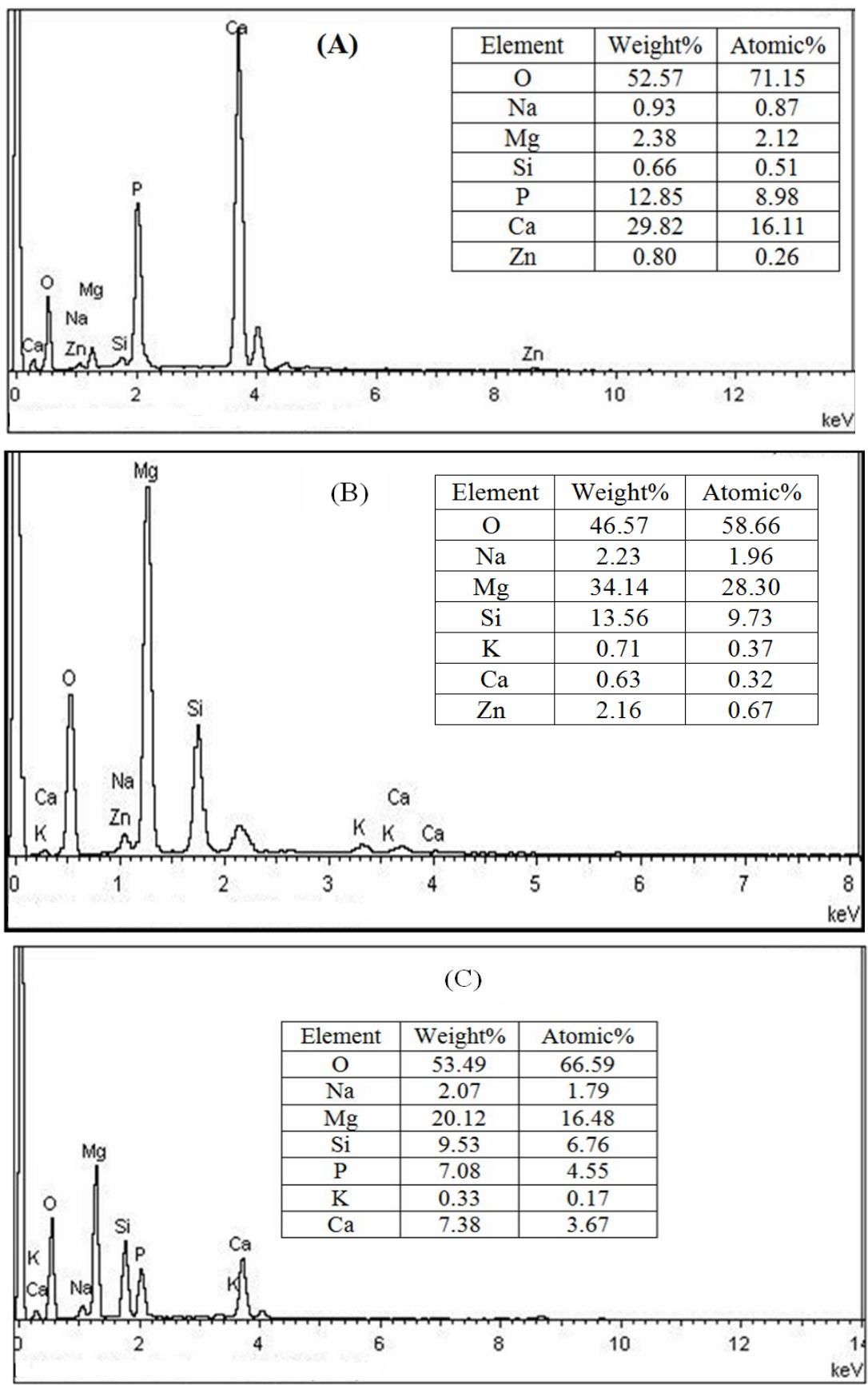

Fig. 2. EDS analyses for FHA coat (a), MOA coat (b), and FHA/MAO coat (c) on Mg-Zn-Ca alloys.

Egypt. J. Chem. 57, No. 2 (2014) 


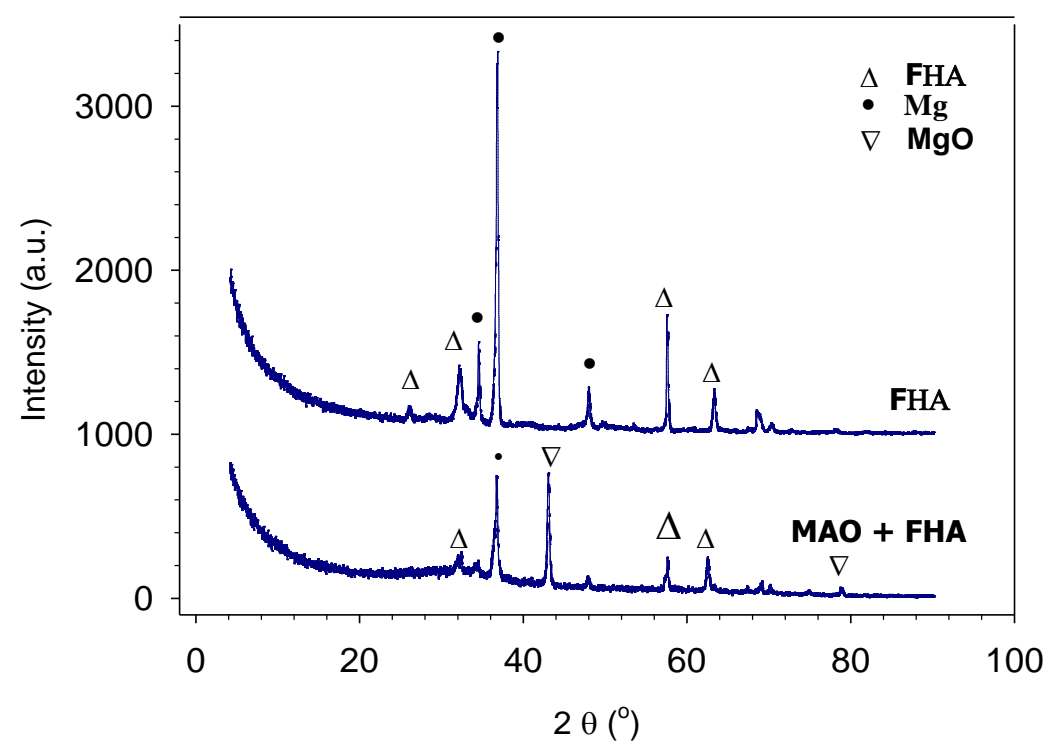

Fig. 3. XRD patterns for FHA and FHA/MOA coatings on Mg-Zn-Ca alloy.

The relatively weak intensity of the FHA may be attributed to the poor crystallinity of the deposited FHA. In the pattern of MAO/FHA coating, FHA and $\mathrm{MgO}$ peaks appear while the intensity of the $\mathrm{Mg}$ peak is largely reduced which indicates the formation of $\mathrm{MgO}$ layer that cover the alloy surface prior to the deposition of FHA top coat.

\section{Electrochemical corrosion test}

Potentiodynamic polarization curves for uncoated, FHA, MAO and FHA/MAO coated samples are shown in Fig.4. For the uncoated and FHA coated samples, It can be seen that the current increases quickly at the beginning of anodic side, then the diffusion-controlled anodic current behavior is observed at the end of the curves due to the high corrosion rate ${ }^{(20)}$. The FHA coated sample exhibits slightly better behavior than the uncoated sample as indicated by lower anodic current. The MAO coated surface illustrates obviously better behavior than either the uncoated or the FHA coated samples. In this case the current remains passive within a potential range of about $0.24 \mathrm{~V}$. The FHA/MAO coated sample displays the best behavior giving the lowest passive current $\left(\sim 10^{-7} \mathrm{~A} \mathrm{~cm}^{-2}\right)$ within a potential range of about $0.3 \mathrm{~V}$. 


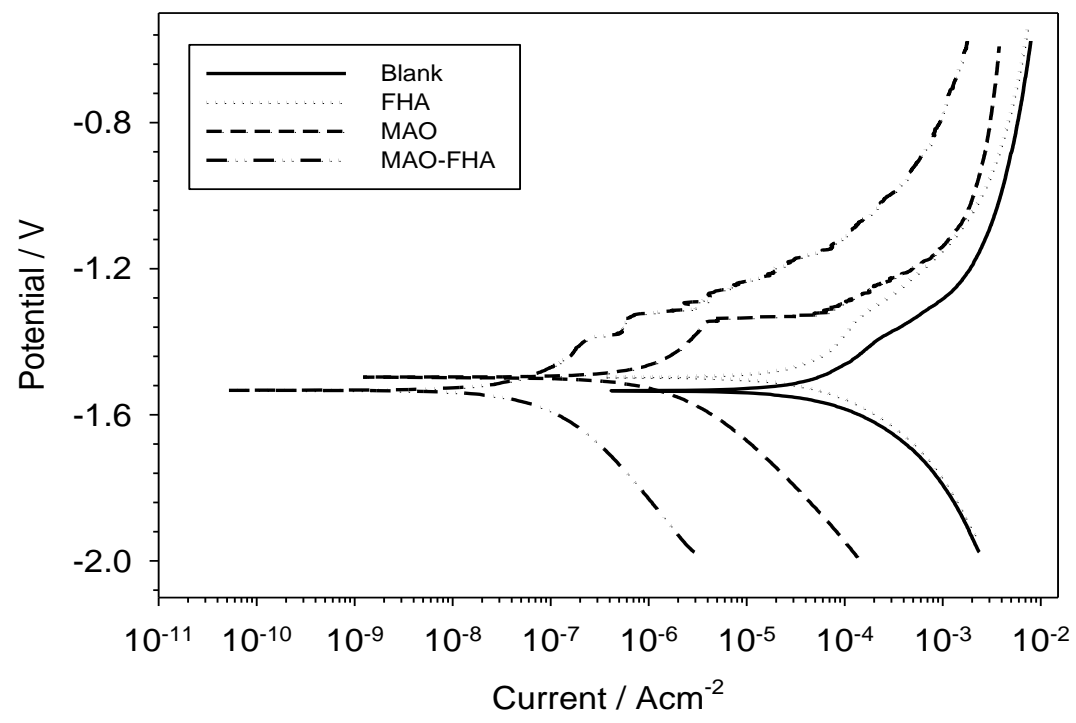

Fig. 4. Potentiodynamic polarization curves of uncoated, FHA, MAO and MAO/FHA coated samples in SBF solution at room temperature.

Potentiodynamic polarization tests indicate that the corrosion current $\left(\mathrm{i}_{\text {corr }}\right)$ for the FHA coating was $4.19 \times 10^{-5} \mathrm{~A} / \mathrm{cm}^{2}$, which is slightly lower than that of substrate $\left(7.5 \times 10^{-5} \mathrm{~A} / \mathrm{cm}^{2}\right)$. The corrosion current decreased down to $1.19 \times 10^{-6}$ through MAO treatment. This value is almost 60 times lower than that of the uncoated sample. The corrosion current is further decreased after FHA coating of the MAO treated sample $\left(4.3 \times 10^{-8}\right)$. The $\mathrm{i}_{\text {corr }}$ of the FHA/MAO coated sample is almost three order of magnitude lower than the uncoated sample and two orders of magnitude lower than the MAO treated sample. Results of potentiodynamic polarization support those of surface investigations.

EIS spectra (Fig. 5) depict that the FHA/MAO coat posses the highest resistance towards corrosion as presented by the largest loop diameter in the Nyquist plot. MAO treated surface shows lower corrosion resistance than the FHA/MAO coat followed by the FHA coat and finally the uncoated surface. The polarization resistance $\left(R_{p}\right)$ values of different samples are derived from the Nyquist plot and presented in Fig. 6. $R_{p}$ values of the MAO/FHA coat is about 14 times higher than those of the uncoated sample, 9 times more than the FHA coated sample and two times more than the MAO treated sample.

Egypt. J. Chem. 57, No. 2 (2014) 


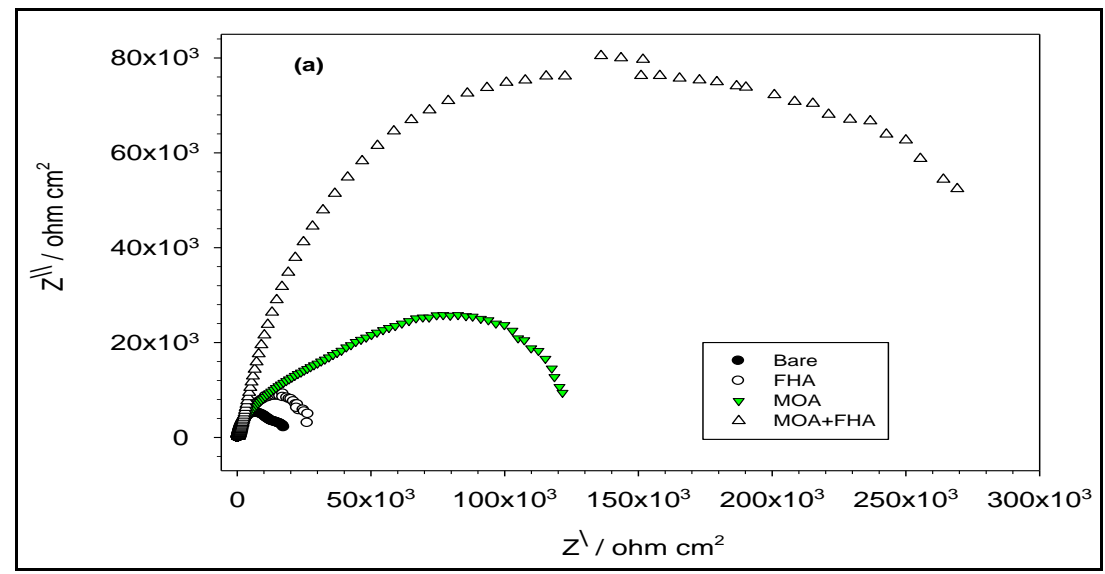

Fig. 5. Electrochemical impedance spectra of bare metal coated with FHA, MAO and FHA/MOA in SBF at room temperature. (a) Nyquist plot (b) and (C) Bode plot.

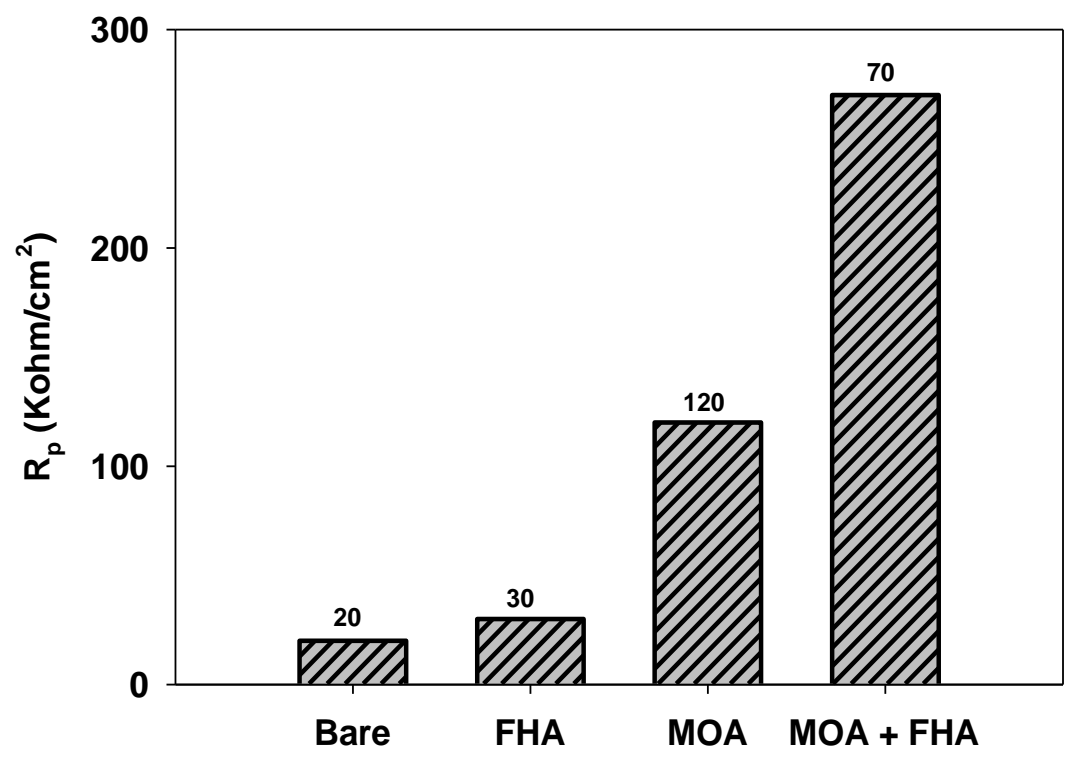

Fig. 6. Polarization resistance of bare metal, FHA, MAO and FHA/MOA coated samples derived from EIS spectra.

The present work addressed the application of MAO/FHA coating on Mg-3Zn$0.8 \mathrm{Ca}$ alloy. The work is an important contribution in revealing the great potential of $\mathrm{Mg}-\mathrm{Zn}-\mathrm{Ca}$ alloys in biomedical applications. $\mathrm{Zn}$ and $\mathrm{Ca}$ play a key role in the Bio-degradation control of $\mathrm{Mg}$ alloys as bio-degradable materials ${ }^{(21-23)}$. $\mathrm{Zn}$ and $\mathrm{Ca}$ can be metabolized and are supplements for human bodies. $\mathrm{Mg}-1 \mathrm{wt} \% \mathrm{Zn}$ produced less hydrogen than many other binary $\mathrm{Mg}$ alloys in simulated body fluid 
(SBF). This alloy also showed lower $\mathrm{Mg}$ and alloying element concentrations than many other binary $\mathrm{Mg}$ alloys in both $\mathrm{SBF}$ and Hank's solution. $\mathrm{Mg}-6 \mathrm{wt}$.\% $\mathrm{Zn}$ is suitable for implant applications in terms of mechanical properties. The cytocompatiblity evaluation revealed that $\mathrm{Mg}-1 \mathrm{wt} \% \mathrm{Ca}$ alloy did not induce toxicity to cells. The $\mathrm{Mg}-3 \mathrm{Zn}-0.8 \mathrm{Ca}$ alloy tested in this paper represented a material system which combined the positive effect of $\mathrm{Zn}$ and $\mathrm{Ca}$ with minimal contents of these elements.

\section{Conclusions}

On the basis of the present study the following conclusions may be drawn:

1) FHA coat slightly enhances the corrosion protection of $\mathrm{Mg}-\mathrm{Zn}-\mathrm{Ca}$ alloy due to poor adhesion to the substrate.

2) MAO treatment has the advantage of excellent adhesive coat but the disadvantage of film-containing pores.

3) $\mathrm{MAO} / \mathrm{FHA}$ treatment is promising treatment for protection of $\mathrm{Mg}$ biodegradable implants due to pore-free and adhesive film formation.

\section{References}

1. Staiger, M.P., Pietaka, A.M., Huadmaia, J. and Dias, G., Magnesium and its alloys as orthopedic biomaterials: a review. Biomaterials, 27, 1728 (2006).

2. Witte, F., Kaese, V., Switzer, H., Meyer-Lindenberg, A., Wirth, C.J. and Windhag, H., In vivo corrosion of four magnesium alloys and the associated bone response, Biomaterials, 26, 3557-3563 (2005).

3. Gu, X., Zheng, Y., Cheng, Y., Zhong, S. and Xi, T., In vitro corrosion and biocompatibility of binary magnesium alloys. Biomaterials, 30, 484 (2009) .

4. Hänzi, A.C., Gerber, I., Schinhammer, M., Löffler, J.F. and Uggowitzer, P.J., 'On the in vitro and in vivo degradation performance and biological response of new biodegradable Mg-Y-Zn alloys'. Acta Biomater. 6 (5), 1824 (2010).

5. Zhang, S., Zhang, X. Zhao, C., Li, J., Song, Y., Xie, C., Tao, H., Zhang, Y., He, Y. and Jiang, Y. Electrodeposition of $\mathrm{Ca}-\mathrm{P}$ coatings on biodegradable $\mathrm{Mg}$ alloy: in vitro biomineralization behavior. Acta Biomater. 6 (2), 626 (2010).

6. Li, Z., Gu, X., Lou, S. and Zheng, Y., The development of binary Mg-Ca alloys for use as biodegradable materials within bone. Biomaterials, 29, 1329 (2008).

7. Song, Y.W., Shan, D.Y., Chen, R.S., Zhang, F. and Han, E.H., Study of second phase in bioabsorbable magnesium alloys: Phase stability evaluation via $\mathrm{Dmol}^{3}$ calculation. Mater. Sci. Eng. C, 29, 1039-1045 (2009) .

8. Shi, Y., Qi, M., Chen, Y. and Shi, P., MAO-DCPD composite coating on Mg alloy for degradable implant applications. Mater. Lett. 65, 2201 (2011).

Egypt. J. Chem. 57, No. 2 (2014) 
9. Gao, J.H., Guan, S.K., Chen, J., Wang, L.G., Zhu, S.J. Hu, J.H. and Ren, Z.W., App. Surf. Sci. 257, 2231(2011).

10. Liu, G.Y., Hu, J., Ding, Z.K. and Wang, C., Formation mechanism of calcium phosphate coating on micro-arc oxidized magnesium, Mater. Chem. Phys. 130, 1118 (2011).

11. Liu, G.Y., Hu, J., Ding, Z.K. and Wang, C., Bioactive calcium phosphate coating formed on micro-arc oxidized magnesium by chemical deposition. App. Surf. Sci. 257, 2051 (2011).

12. Gu, X.N., Li, N., Zhou, W.R., Zheng, Y.F., Zhao, X. Cai, Q.Z. and Ruan, L., Bioactive calcium phosphate coating formed on micro-arc oxidized magnesium by chemical deposition. Acta Biomater. 7, 1880 (2011).

13. Chen, J., Zeng, R.C., Huang, W.J., Zheng, Z.Q., Wang, Z.L. and Wang, Z.L., Corrosion resistance and surface biocompatibility of a microarc oxidation coating on a $\mathrm{Mg}-\mathrm{Ca}$ alloy. Trans. Nonferr. Met. Soc., 18, S361 (2008).

14. Kaesel, V.T., Tai, P.T. and Bach, F.W., In: Kainer K U, (Ed). Proceedings of the Sixth International Conference on Magnesium Alloys and Their Applications. New York: Wiley-Vch, 534 (2004).

15. Meng, E.C., Guan, S.K., Wang, H.X., Wang, L.G., Zhu, S.J., Hu, J.H., Ren, C.X., Gao, J.H. and Feng, Y.S. Effect of electrodeposition mode on surface characteristics and corrosion properties of fluorine doped hydroxiapatite coatings on $\mathrm{Mg}-\mathrm{Zn}-\mathrm{Ca}$ alloy. App. Surf. Sci. 257, 48 (2011).

16. Wang, J., Chao, Y., Wan, Q., Zhu, Z. and Yu, H., Fluoridated hydroxyapatite coatings on titanium obtained by electrochemical deposition. Acta Biomater. 5,1798 (2009).

17. Song, G.L., Control of biodegradation of biocompatable magnesium alloys. Corros. Sci. 49,1696 (2007).

18. Dumelie, N., Benhayoune, H., Richard, Laurent-Maquin, D. and Balossier, G., In vitro precipitation of electrodeposited calcium-deficient hydroxyapatite coatings on Ti6Al4V substrate. Mater. Character. 59,129 (2008).

19. Monteiro, M.M., Rocha, N.C.C., Rossi, A.M. and Soares, G.A., Dissolution properties of calcium phosphate granules with different compositions in simulated body fluid. $J$. Biomed. Mater. Res. A, 65 (2), 299 (2003).

20. Cao, C.N., The Principles of Corrosion Electrochemistry, $2^{\text {nd }}$ ed., Chemical Industry Press, Beijing, 120-122. Z (2004).

21. Xu, Z., Smith, C., Chen, S. and Sankar, J., Development and microstructural characterizations of $\mathrm{Mg}-\mathrm{Zn}-\mathrm{Ca}$ alloys for biomedical applications. Materials Science and Engineering B, 176,1660 (2011).

22. Wanga, H., Guana, S., Wangc, Y., Liuc, H., Wangc, H., Wanga, L., Rena, C., Zhua, S. and Chend, K., In vivo degradation behavior of Ca-deficient hydroxyapatite 
coated $\mathrm{Mg}-\mathrm{Zn}-\mathrm{Ca}$ alloy for bone implant application. Colloids and Surfaces B: Biointerfaces, 88, 254 (2011)

23. Zhang, S., Zhang, X., Zhao, C., Li, J., Song, Y., Xie, C., Tao, H., Zhang, Y., He, Y., Jiang, Y. and Bian, Y., Research on an Mg-Zn alloy as a degradable biomateria 1 Acta Biomater. 6, 626-640 (2010).

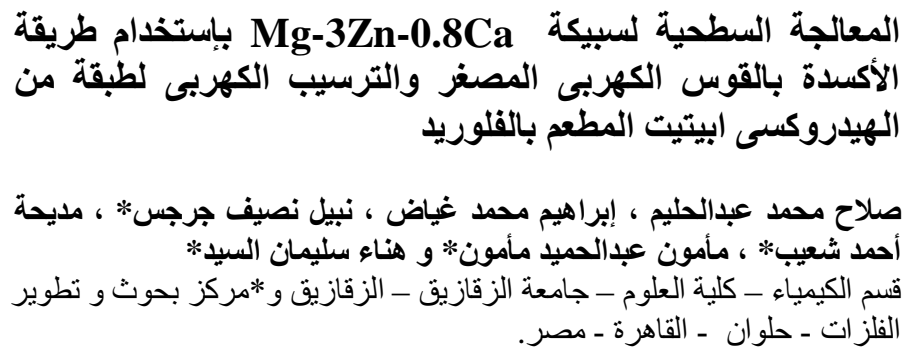

توجد العديد من الصعوبات التى تحد من إستخدام سبائك الماغنسيوم فى مجال

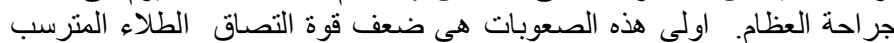

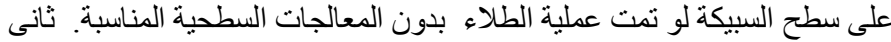

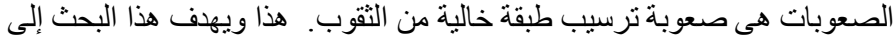

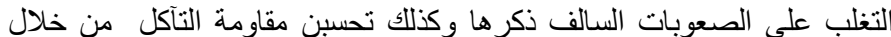
المعالجة السطحية والترسيب الكهربى على سطح ولى السبيكة.

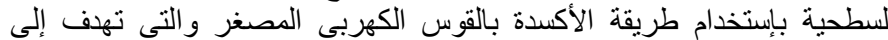

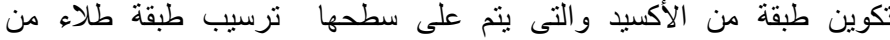

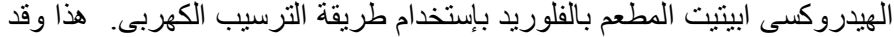

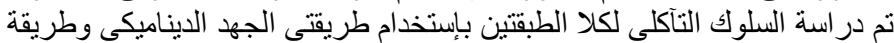

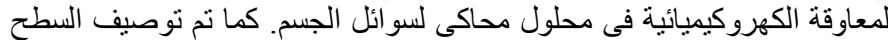

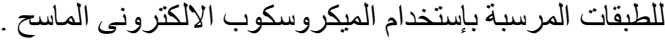

وقد أوضحت النتائج أن الأكسدة بالقوس الكهربى المصغر تؤدي إلى تقليل

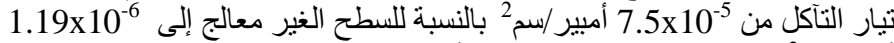

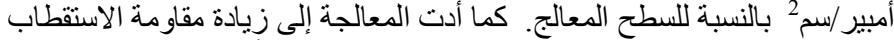

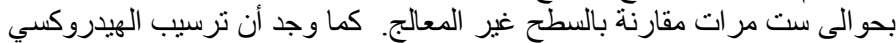

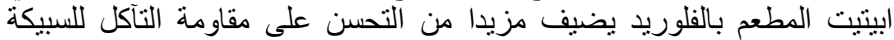

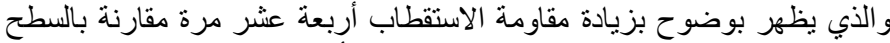

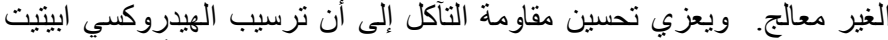

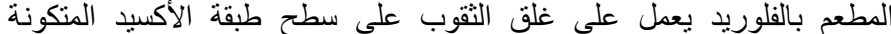

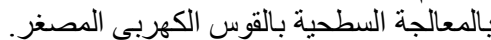

